\title{
Induced Expression of Syndecan-1 in the Stroma of Head and Neck Squamous Cell Carcinoma
}

Perkins Mukunyadzi, M.D., Kela Liu, M.D., Ph.D., Ehab Y. Hanna, M.D., James Y. Suen, M.D., Chun-Yang Fan, M.D., Ph.D.

Departments of Pathology (PM, KL, C-YF) and Otolaryngology and Head and Neck Surgery (EYH, JYS), University of Arkansas for Medical Sciences and Central Arkansas Veterans Healthcare System, Little Rock, Arkansas

Syndecan-1 (CD138), a cell-surface heparan sulfate proteoglycan, is involved in cell-cell, cell-matrix interaction and growth factor binding. Loss of expression of syndecan-1 in tumor cells leads to decreased intercellular cohesion, increased potential for tumor invasiveness, and metastatic spread. Furthermore, induction of syndecan-1 expression in the tumor stroma has been postulated to promote tumor angiogenesis via its binding to growth factors such as basic fibroblast growth factor. Although syndecan-1 expression within tumor cells has been investigated in head and neck squamous cell carcinoma, stromal expression has not been studied in detail. We analyzed 38 cases of head and neck squamous cell carcinoma by immunohistochemical staining for syndecan-1 expression within the stroma. The expression of syndecan-1 within tumor cells of various histologic grades of differentiation, squamous cell carcinoma in situ cells, and benign squamous epithelium was also determined. Variable levels of diminished syndecan-1 expression were noted within the dysplastic cells of 9 of 16 (60\%) squamous cell carcinoma in situ lesions and in all $38(100 \%)$ invasive squamous cell carcinoma. In general, higher levels of syndecan-1 expression were observed in the well-differentiated tumors, in contrast to significant reduction of expression seen in poorly differentiated tumors. Syndecan-1 expression was observed within the stroma (in fibroblasts) surrounding infiltrating carcinoma cells in 28 of $\mathbf{3 8}$ (74\%) cases. The intensity of syndecan-1 staining within the stroma showed generally an inverse correlation with the degree of tumor cell differentia-

Copyright (C 2003 by The United States and Canadian Academy of Pathology, Inc.

VOL. 16, NO. 8, P. 796, 2003 Printed in the U.S.A.

Date of acceptance: May 1, 2003.

Address reprint requests to: Perkins Mukunyadzi, M.D., Department of Pathology, University of Arkansas for Medical Sciences, 4301 W. Markham Street, Little Rock, AR 72205; fax: 501-603-1479; e-mail: mukunyadziperkins@uams.edu.

DOI: 10.1097/01.MP.0000081731.17549.53 tion. Syndecan-1 expression was not detected in the stroma beneath normal squamous epithelium or adjacent to areas of squamous cell carcinoma in situ. We conclude that induced expression of syndecan-1 in the stroma surrounding tumor cells of invasive head and neck squamous cell carcinoma is a frequent event. The increased stromal syndecan-1 expression, coupled with its loss from the surface of carcinoma cells, may contribute to tumor cell invasion and the development of metastases.

KEY WORDS: Expression, Head and neck, Squamous cell carcinoma, Stroma, Syndecan-1.

Mod Pathol 2003;16(8):796-801

The syndecan molecules are cell surface adhesion molecules belonging to the heparan sulfate proteoglycan family. Among their many biological functions, syndecans are involved in cell-cell adhesion and interactions with the extracellular matrix and are capable of binding several ligands, including growth factors. Thus, syndecans play a critical role in cell growth, differentiation, cell morphology, and migration. Four members of the syndecan family have been identified and include sydecan-1, -2, -3 , and -4 . Each syndecan molecule consists of a amino $\left(\mathrm{NH}_{2}-\right)$ terminal extracellular domain that provides attachment sites for three to eight glycosaminoglycan chains, an internal hydrophobic transmembrane domain, and a relatively short carboxy $(\mathrm{COOH}-)$ terminal cytoplasmic domain $(1,2)$.

The best-known member of the syndecan family, which has been extensively studied, is syndecan-1. The interaction of syndecan- 1 with the extracellular matrix includes binding to both insoluble and soluble molecules within the matrix such as interstitial collagens, fibronectin, tenascin, thrombospondin, basic fibroblast growth factors (bFGF), and others (1, 3-6).

During embryonic development, syndecan-1 expression can be detected in both mesenchymal and 
epithelial cells. In mature tissue, however, syndecan-1 expression is localized entirely to the epithelial cells, with stratified squamous epithelia showing the most abundant expression (7-9).

Head and neck squamous cell carcinoma is a common malignancy accounting for approximately 50,000 new cases every year in the United States (10). The etiology is multifactorial, with tobacco smoking and various genetic alterations having been implicated (11). It has been shown that the expression of syndecan- 1 is diminished in head and neck squamous cell carcinoma and other carcinomas (12-14). The level of syndecan-1 expression in tumor cells inversely correlates with tumor invasiveness, metastatic potential, and overall prognosis. Recently, Stanley and colleagues (15) reported syndecan-1 expression within the stroma surrounding infiltrating tumor cells of breast ductal carcinoma. It has been speculated that stromal syndecan-1 may facilitate tumor growth by potentially promoting angiogenesis (15). The expression of syndecan-1 in the stroma of head and neck squamous cell carcinoma has, however, not been investigated in detail or reported. We performed an immunohistochemical analysis of syndecan-1 expression in the stroma of head and neck squamous cell carcinoma and stroma beneath benign squamous mucosa.

\section{MATERIALS AND METHODS}

The computer database and the pathology files at the University of Arkansas for Medical Sciences and the Central Arkansas Veterans Healthcare System were searched for cases of squamous cell carcinoma of the head and neck area. A total of 38 cases of head and neck squamous cell carcinoma diagnosed over a 4-year period, 1995 to 1999, with suitable archival paraffin tissue blocks, was identified, retrieved, and prepared for analysis of syndecan-1 expression by immunohistochemistry (Table 1).

The tissue specimens were fixed in $10 \%$ buffered formalin and embedded in paraffin. Sections $4 \mu \mathrm{m}$ in thickness were cut and mounted on silanecoated slides, air dried, and deparaffinized, followed by antigen retrieval with the steam heat method for 40 minutes using the DAKO Target Retrieval solution (DAKO, Carpinteria, CA). The endogenous peroxidase activity was quenched with $0.3 \%$ hydrogen peroxide for 10 minutes and nonspecific binding blocked by goat serum for $30 \mathrm{~min}$ utes. Using the DAKO Large Volume LSAB2 Alkaline Phosphatase Kit (DAKO), the tissue sections were incubated with the B-B4 primary antibody (Serotec, Raleigh, NC) at a dilution of 1:100 at room temperature for 80 minutes. The B-B4 antibody is a mouse anti-human antibody that recognizes an epitope found on human syndecan-1 (CD 138; 16). Sections were then incubated with the biotinylated secondary antibody for 30 minutes, followed by incubation with streptavidin alkaline phosphatase for another 30 minutes. 2'3'-Diamino-dibenzedene was used to visualize the end product. Appropriate washes of the sections with phosphate buffered saline were performed between each step. Normal skin with strong syndecan-1 expression in the keratinocytes was used as the positive control, whereas the negative control consisted of a 1:100 dilution of a nonspecific isotype-matched IG1 mouse antibody, MCA 928 (Serotec, Raleigh, NC), that was substituted for the B-B4 antibody. The slides were counterstained with hematoxylin before dehydration and cover slipping.

The sections were analyzed and staining assessed using a semiquantitative grading system as follows: negative (-), complete lack of staining or staining in $<10 \%$ of tumor cells; weak $(+)$, staining in 10 to $20 \%$ of tumor cells; mild $(++)$, staining in 20 to $50 \%$ of tumor cells; moderate $(+++)$, staining in 50 to $70 \%$ of tumor cells; strong $(++++)$, staining in $>70 \%$ of tumor cells. Stromal syndecan-1 expression was similarly evaluated, with the level of expression semiquantitatively scored relative to the overall quantity of stroma surrounding the tumor cells.

\section{RESULTS}

\section{Pathologic Findings}

The hematoxylin and eosin sections were examined to confirm the diagnosis. There were 16 cases of squamous cell carcinoma in situ (CIS) and 38 invasive squamous cell carcinoma. On the basis of histologic features, the invasive tumors were subdivided into well differentiated $(19,50 \%)$, moderately differentiated $(5,13 \%)$, and poorly differentiated $(14,37 \%)$ grades. Clearly identifiable stroma was present in the subepithelial area of the in situ lesions, in surrounding tumor cells, and beneath benign squamous mucosa (Table 1).

\section{Syndecan-1 Immunoreactivity}

Diminished levels of syndecan-1 expression were observed in all $38(100 \%)$ invasive squamous cell carcinoma and in 9 of $16(60 \%)$ squamous cell CIS lesions. In general, although overall there was reduction in the level of staining in the invasive tumors, the level of expression was higher in the better-differentiated tumors than in tumors or areas showing poorly differentiated carcinoma cells. Complete lack of staining was seen in 3 (8\%) cases, whereas mild, moderate, and strong staining was present in $4(11 \%), 18(47 \%)$, and 0 of the 
Table 1. Clinical Data, Follow-Up, and Syndecan-1 Immunohistochemistry in 38 Cases of Head and Neck Squamous Cell Carcinoma q

\begin{tabular}{|c|c|c|c|c|c|c|c|c|c|c|}
\hline $\begin{array}{c}\text { Case } \\
\#\end{array}$ & $\begin{array}{c}\text { Age/ } \\
\text { Sex }\end{array}$ & Tumor Site & $\begin{array}{l}\text { Tumor } \\
\text { Grade }\end{array}$ & $\begin{array}{l}\text { Initial } \\
\text { Node } \\
\text { Status }\end{array}$ & $\begin{array}{l}\text { Syn-1 } \\
\text { Staining in } \\
\text { Tumor }\end{array}$ & $\begin{array}{c}\text { Syn-1 } \\
\text { Staining } \\
\text { in Stroma }\end{array}$ & $\begin{array}{l}\text { TNM } \\
\text { Stage }\end{array}$ & $\begin{array}{l}\text { Initial } \\
\text { Therapy }\end{array}$ & $\begin{array}{l}\text { Recurrence } \\
\text { (months) }\end{array}$ & $\begin{array}{c}\text { Follow-Up } \\
\text { (months) }\end{array}$ \\
\hline 1 & $72 / \mathrm{m}$ & Vocal cord & PD & Yes & + & ++ & T1N0M0 & Resection & No & Dead, 52 \\
\hline 2 & $61 / \mathrm{m}$ & Vocal cord & PD & No & + & ++++ & T2N2M0 & Resection & $Y, 52$ & Alive, 69 \\
\hline 3 & $52 / \mathrm{m}$ & Larynx & WD & No & +++ & + & T1N0M0 & DXT & No & Dead, 20 \\
\hline 4 & $79 / \mathrm{m}$ & Vocal cord & $\mathrm{PD}$ & Yes & +++ & ++ & T1N0M0 & Resection & $\mathrm{Y}, 9$ & Dead, 60 \\
\hline 5 & $65 / \mathrm{m}$ & Vocal cord & PD & Yes & +++ & ++++ & T1N0M0 & DXT & No & Alive, 64 \\
\hline 6 & $78 / \mathrm{m}$ & Tongue & PD & No & +++ & - & T1N0M0 & Resection & No & Dead, 64 \\
\hline 7 & $42 / \mathrm{m}$ & Larynx & MD & No & +++ & + & T2N0M0 & Resection & No & Dead, 8 \\
\hline 8 & $80 / \mathrm{m}$ & FOM & MD & No & +++ & ++ & T1N0M0 & Resection & $\mathrm{Y}, 19$ & Lost \\
\hline 9 & $78 / \mathrm{m}$ & Gingiva & $\mathrm{PD}$ & No & ++ & - & T1N0M0 & Resection & No & Lost \\
\hline 10 & $83 / \mathrm{m}$ & Tonsil & PD & No & ++ & +++ & T2N0M0 & Resection/DXT & No & Dead, 24 \\
\hline 11 & $83 / \mathrm{m}$ & Lip & PD & No & +++ & - & T1N0M0 & Resection & No & Dead, 55 \\
\hline 12 & $55 / \mathrm{m}$ & $\mathrm{BM}$ & PD & No & + & +++ & T1N0M0 & Resection/DXT & No & Lost \\
\hline 13 & $84 / \mathrm{m}$ & Vocal cord & PD & No & +++ & + & T4N1M0 & Resection & No & Alive, 56 \\
\hline 14 & $69 / \mathrm{m}$ & Vocal cord & PD & No & +++ & ++ & T1N0M0 & Resection/DXT & No & Dead, 59 \\
\hline 15 & $81 / \mathrm{m}$ & Vocal cord & PD & No & ++ & + & T1N0M0 & DXT & No & Alive, 52 \\
\hline 16 & $74 / \mathrm{m}$ & Vocal cord & WD & No & +++ & ++ & T1N0M0 & DXT & No & Dead, 55 \\
\hline 17 & $76 / \mathrm{m}$ & Vocal cord & WD & No & ++ & + & T1N0M0 & DXT/Chemo & No & Alive, 38 \\
\hline 18 & $65 / \mathrm{m}$ & Tongue & WD & No & +++ & +++ & T1N0M0 & Resection & $\mathrm{Y}, 6$ & Alive, 36 \\
\hline 19 & $80 / \mathrm{m}$ & Pharynx & PD & No & ++ & - & T1N0M0 & Resection & No & Dead, 4 \\
\hline 20 & $63 / \mathrm{m}$ & Tongue & PD & No & - & - & T1N0M0 & Resection/DXT & No & Alive, 63 \\
\hline 21 & $78 / \mathrm{m}$ & Gum & $\mathrm{WD}$ & No & ++ & + & T3N1M0 & Resection & No & Lost \\
\hline 22 & $80 / \mathrm{m}$ & Tonsil & WD & No & ++ & +++ & T1N0M0 & Resection/DXT & No & Dead, 24 \\
\hline 23 & $62 / \mathrm{m}$ & Tonsil & WD & Yes & ++ & + & T4N2M1 & DXT & $\mathrm{Y}, 9$ & Dead, 17 \\
\hline 24 & $61 / \mathrm{m}$ & FOM & WD & No & - & + & T2N0M0 & Resection & $\mathrm{Y}, 36$ & Dead, 44 \\
\hline 25 & $78 / \mathrm{m}$ & Vocal cord & WD & Yes & ++ & + & T1N0M0 & DXT & $\mathrm{Y}, 10$ & Dead, 37 \\
\hline 26 & $79 / \mathrm{m}$ & Lip & WD & No & ++ & - & T1N0M0 & DXT & No & Dead, 41 \\
\hline 27 & $78 / \mathrm{m}$ & FOM & MD & No & ++ & + & T1N0M0 & Resection & $\mathrm{Y}, 9$ & Dead, 35 \\
\hline 28 & $52 / \mathrm{m}$ & Vocal cord & $\mathrm{WD}$ & No & ++ & - & T1N0M0 & Resection/DXT & No & Lost \\
\hline 29 & $80 / \mathrm{m}$ & FOM & MD & No & ++ & - & T1N0M0 & DXT/Chemo & $\mathrm{Y}, 48$ & Alive, 56 \\
\hline 30 & $68 \mathrm{~m}$ & Vocal cord & $\mathrm{WD}$ & No & ++ & + & T4N0M0 & Resection & $\mathrm{Y}, 2$ & Dead, 59 \\
\hline 31 & $80 / \mathrm{m}$ & Vocal cord & $\mathrm{WD}$ & Yes & - & ++ & T1N0M0 & DXT & No & Alive, 54 \\
\hline 32 & $61 / \mathrm{m}$ & Soft palate & WD & No & ++ & - & T2N0M0 & Resection & No & Alive, 53 \\
\hline 33 & $73 / \mathrm{m}$ & Vocal cord & WD & No & ++ & + & T1N0M0 & DXT & No & Dead, 33 \\
\hline 34 & $75 / \mathrm{m}$ & Lip & WD & No & ++ & - & T1N0M0 & Resection & No & Alive, 52 \\
\hline 35 & $75 / \mathrm{m}$ & Vocal cord & WD & No & ++ & + & T1N0M0 & Resection & $\mathrm{Y}, 18$ & Alive, 38 \\
\hline 36 & $65 / \mathrm{m}$ & Tongue & MD & No & + & + & T1N0M0 & DXT & No & Alive, 36 \\
\hline 37 & $60 / \mathrm{m}$ & Pharynx & WD & No & +++ & +++ & T1N0M0 & Resection/DXT & No & Dead, 40 \\
\hline 38 & $81 / \mathrm{m}$ & FOM & WD & No & +++ & ++ & T1N0M0 & Resection & No & Dead, 12 \\
\hline
\end{tabular}

$\mathrm{WD}=$ well differentiated; $\mathrm{MD}=$ moderately differentiated; $\mathrm{PD}=$ poorly differentiated; $\mathrm{FOM}=$ floor of mouth; $\mathrm{TNM}=$ tumor node metastases; $\mathrm{DXT}=$ radiation therapy; Chemo = chemotherapy; Syn-1 = syndecan-1.

Table 2. Summary of Syndecan-1 Immunostaining Results within Tumor Cells and Stroma

\begin{tabular}{lccrrrr}
\hline Extent \& Staining Intensity & $\begin{array}{c}\text { Negative } \\
(-)\end{array}$ & $\begin{array}{c}\text { Weak } \\
(+)\end{array}$ & $\begin{array}{c}\text { Mild } \\
(++)\end{array}$ & $\begin{array}{c}\text { Moderate } \\
(+++)\end{array}$ & $\begin{array}{r}\text { Strong } \\
(++++)\end{array}$ & $\begin{array}{c}\text { Total } \\
\text { Tumor cells }\end{array}$ \\
\hline Stromal staining (fibroblasts) & $10(8 \%)$ & $4(11 \%)$ & $18(47 \%)$ & $13(34 \%)$ & $0(0 \%)$ & 38 \\
\hline
\end{tabular}

Negative (-), complete lack of staining or staining in less than $10 \%$ of tumor cells; weak (+), staining in 10 to $20 \%$ of tumor cells; mild $(++)$, staining in 20 to $50 \%$ of tumor cells; moderate $(+++)$, staining in 50 to $70 \%$ of tumor cells; strong $(++++)$, staining in more than $70 \%$ of tumor cells.

cases, respectively (Table 2). In normal squamous epithelium, the staining for syndecan-1 was mostly along the cytoplasmic membrane, with little or no cytoplasmic staining (Fig. 1A), whereas cells of CIS showed increased cytoplasmic staining and diminished membranous (cytoplasmic) staining (Fig. 1B). Whereas the well-differentiated squamous cell carcinoma cells maintained membranous staining, concomitant cytoplasmic staining was also prominent (Fig. 1C). However, cases of invasive squamous cell carcinoma with predominantly cytoplasmic staining and no membranous expression were also seen (Fig. 1D). Ex- pression of syndecan-1 within the stroma, specifically within fibroblasts, surrounding tumor cells was detected in 28 (74\%) cases of squamous cell carcinoma (Fig. 1E). In these cases, staining was weak in $14(37 \%)$, mild in $7(18 \%)$, moderate in $5(13 \%)$, and strong in $2(5 \%)$ cases and was predominantly seen in the vicinity of the infiltrating tumor cells. Other stromal cells such as adipocytes and endothelial and inflammatory cells did not express syndecan-1. The stromal expression of syndecan-1 was present in all grades of invasive squamous cell carcinoma, although generally the intensity of expression was higher in 
the high-grade (poorly differentiated) tumors. This finding is in contrast to the pattern of syndecan-1 surface expression in epithelial tumor cells, in which greater intensity of expression is seen in well-differentiated squamous cell carcinoma and is reduced or absent in the poorly differentiated tumors. The intensity of stromal syndecan-1 expression appeared to vary also with the pattern of tumor invasiveness, with greater intensity seen in many tumors that invaded as single cells or in small groups (less cohesive) than in tumors infiltrating as broad cohesive nests.

There was no syndecan-1 expression detected in the stroma underneath the dysplastic cells of CIS lesions or normal squamous epithelium (Fig. $1 \mathrm{~F})$.
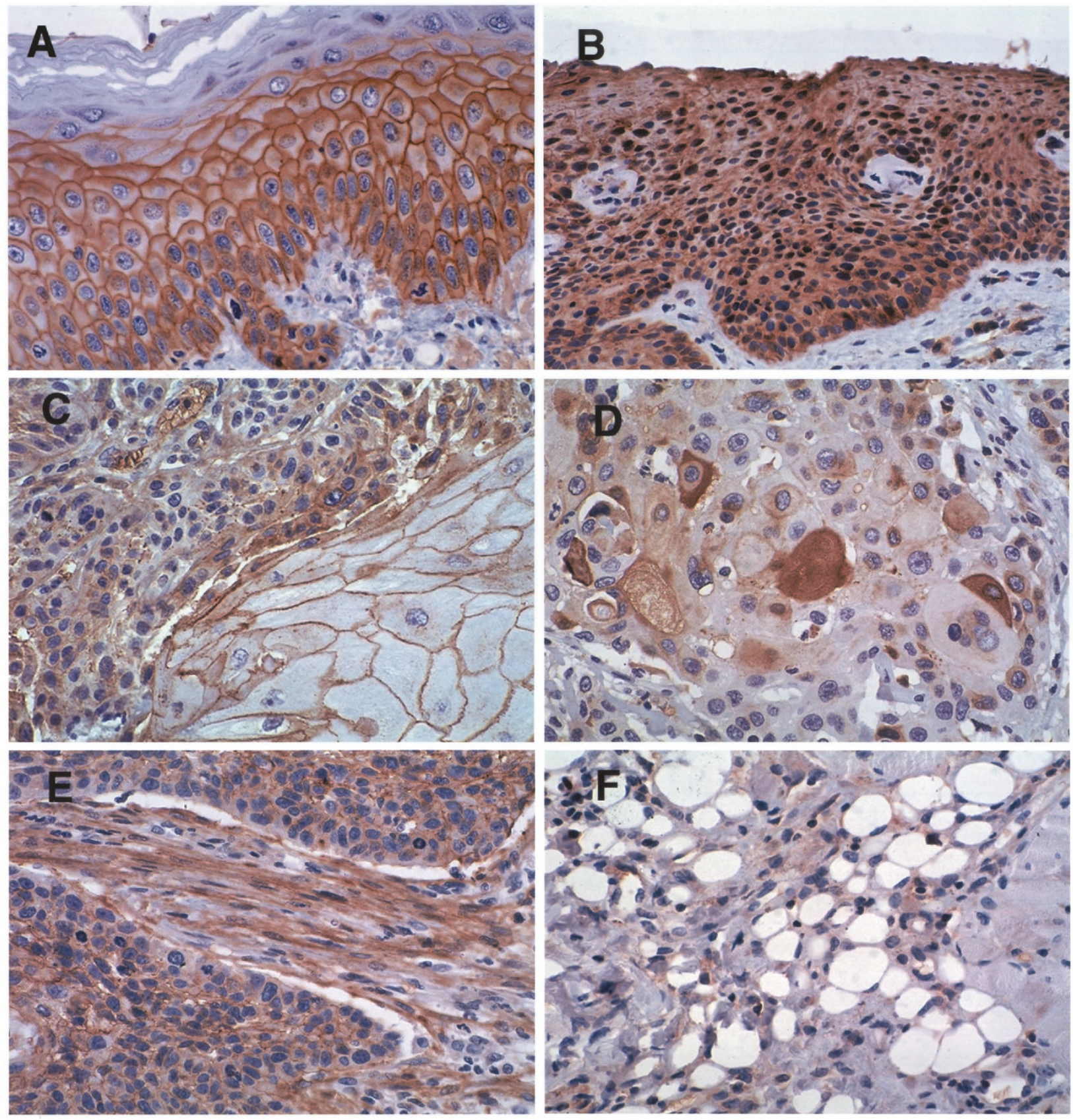

FIGURE 1. Immunohistochemical staining for syndecan-1. A, normal squamous epithelium demonstrates circumferential membranous syndecan-1 staining with weak or absent cytoplasmic staining. B, in situ squamous cell carcinoma loses the membranous syndecan-1 staining seen in normal squamous epithelium but shows increased cytoplasmic staining. $\mathbf{C}$, in invasive carcinoma, well-differentiated carcinoma cells maintain some membranous staining syndecan-1 staining with concomitant cytoplasmic staining. $\mathbf{D}$, in some invasive tumors, syndecan-1 cytoplasmic staining becomes very prominent. E, frequently but not always, fibroblastic stromal cells intimately associated with invasive carcinoma show syndecan-1 expression, which is not seen in the stroma far away from invasive carcinoma (F) and in the stroma directly beneath normal squamous epithelium (A) and in situ carcinoma (B). 


\section{Follow-Up}

The patient follow-up period averaged 42.7 months (range, 4 to $69 \mathrm{mo}$ ) (Table 1). Of the 33 patients for whom follow-up data was available, 20 (61\%) died of the disease, and 13 (39\%) were alive at the last follow-up. Five patients were lost to followup. Statistical analysis showed no direct significant independent prognostic value of stromal syndecan-1 expression. However, 15 (75\%) of the patients dying of the cancer showed syndecan-1 expression in the stroma. Notably, stromal syndecan-1 expression was seen only in invasive tumors and was not detected in CIS lesions.

\section{DISCUSSION}

Previous studies have shown reduced levels of syndecan-1 expression within tumor cells of invasive head and neck squamous cell carcinoma and have shown that this reduction was associated with poor prognosis $(13,14,17)$. However, syndecan-1 expression in the stroma of head and neck squamous cell carcinoma has not been reported before, prompting this investigation. In a study of breast carcinoma, Stanley and colleagues (15) observed syndecan-1 expression within the stroma surrounding infiltrating tumor cells.

In the present study, reduced syndecan-1 expression was observed within the malignant epithelia of CIS (9 of 16, $60 \%$ ) and in all (100\%) of the invasive squamous cell carcinoma, confirming previous findings by other investigators $(14,13)$. The malignant transformation of an epithelial cell is associated with loss of syndecan-1, consequently leading to diminished cell adhesion and anchorage independence $(18,19)$. Thus, tumor cells that are no longer bound to each other or anchored to the extracellular matrix are capable of migrating and invading the adjacent stroma. The diminished expression of surface syndecan-1 is initially observed in dysplastic and in CIS lesions, then becoming more pronounced in invasive tumors $(12,20,21)$. It appears therefore that the loss of syndecan-1 is an early event that shows a temporal progressive pattern of reduction and may be associated with the transition from in situ to invasive tumors.

We observed syndecan-1 expression in the stroma in close proximity and immediately surrounding infiltrating tumor cells in 28 of 38 (74\%) cases of head and neck squamous cell carcinoma. Acquisition of invasive properties by tumor is associated with the ability of the cells to grow beyond the basement membrane, invade into the stroma, and anchor at a new site and initiate further tumor growth $(20,18)$. These biologic activities might be expected to involve the interaction of adhesion molecules and the stroma. In many invasive can- cers, the stroma is not passively infiltrated by tumor cells but shows microscopic evidence of active response in the form of desmoplasia, indicating proliferation of myofibroblasts and mesenchymal cells (18). It is therefore not surprising that desmoplastic stroma, in response to infiltrating tumor cells, may be induced to express syndecan-1. The stromal expression of syndecan-1 appears related to the histologic tumor grade, as nests of more poorly differentiated tumor cells are associated with higher levels of stromal syndecan-1 expression, whereas better differentiated tumor cells show relatively lower levels of stromal syndecan-1 expression (14, 13). In contrast, noninvasive squamous lesions and normal squamous mucosa are not associated with any detectable stromal syndecan-1 expression.

There is molecular evidence of an active role played by the stroma in the biologic course of tumors. It has been demonstrated that there are specific stromal genes that are expressed in response to infiltrating tumor cells. Iacobuzio-Donahue and colleagues (22) demonstrated specific gene expression patterns in the desmoplastic stroma of breast carcinoma. Using cDNA microarrays, they showed, in a profile of breast cancer "invasion-specific" cluster, specific panstromal expression of the collagen $1 \alpha 1$ gene and osteonectin gene expression restricted to the stroma adjacent to tumor cells. The mechanisms responsible for the expression of these genes, stromal induction of syndecan-1 expression, and its loss from the surfaces of malignant epithelia are not fully understood. It has also been noted that in certain situations, nonmalignant mesenchymal cells are capable of expressing syndecan-1. In wound healing, syndecan-1 expression was observed in the developing tissues and myofibroblastic cells, whereas studies in tooth development and recombination experiments have shown that large quantities of syndecan-1 are produced by mesenchymal cells and that this may be under the influence of epithelial cells $(8,23)$. Another potential source of syndecan- 1 is shed or degraded fragments of syndecan-1 (from tumor cells) trapped in the stroma, which are still capable of biological activity, such as binding extracellular ligands (24).

Stromal induction of syndecan-1 may contribute to the invasiveness and/or metastatic potential of the tumors, through mechanisms unrelated to the loss of surface syndecan-1 from the malignant cells. Syndecan-1 or its degradation fragments are capable of binding to bFGF, a potent angiogenic growth factor (24). Through this interaction with bFGF and also vascular endothelial growth factor (VEGF), syndecan-1 may thus help induce neovascularization and hence promote tumor growth and progression $(2,24)$.

In summary, stromal expression of syndecan-1 in head and neck squamous cell carcinoma appears to 
be a frequent event. This induction of syndecan-1 within the stromal cells, coupled with its loss from the surface of malignant tumor cells, may be critical in promoting tumor invasiveness and the development of metastasis, thus contributing to an aggressive biologic behavior.

\section{REFERENCES}

1. Bernfield M, Kokenyesi R, Kato M, Hinkes MT, Spring J, Gallo RL, et al. Biology of the syndecans: a family of transmembrane heparan sulfate proteoglycans. Annu Rev Cell Biol 1992;8:365-93.

2. Carey DJ. Syndecans: multifunctional cell-surface coreceptors. Biochem J 1997;327:1-16.

3. Sun X, Mosher DF, Rapreager A. Heparan sulfate-mediated binding of epithelial cell surface proteoglycan to thrombospondin. J Biol Chem 1989;264:2885-9.

4. Sanders S, Bernfield M. Cell surface proteoglycan binds mouse mammary epithelial cells to fibronectin and behaves as a receptor for interstitial matrix. J Cell Biol 1w988;206:42330 .

5. Salmivirta M, Elenius K, Vainio S, Hofer U, ChiquetEhrismann R, Thesleff I, et al. Syndecan from embryonic tooth mesenchyme binds tenascin. J Biol Chem 1991;266: 7733-9.

6. Koda J, Rapraeger A, Bernfield M. Heparan sulfate proteoglycans from mouse mammary epithelial cells: cell surface proteoglycan as a receptor for interstitial collagens. J Biol Chem 1985;260:8157-62.

7. Sanderson RD, Hinkes M, Bernfield M. Syndecan-1, a cell surface proteoglycan, changes in size and abundance when keratinocytes stratify. J Invest Dermatol 1992;99:390-6.

8. Vainio S, Jalkanen M, Vaahtokari A, Sahlberg C, Mali M, Bernfiled M, et al. Expression of syndecan gene is induced early, is transient, and correlates with changes in mesenchymal cell proliferation during tooth organogenesis. Dev Biol 1991;114:322-33.

9. Vainio S, Jalkanen M, Bernfield M, Saxen L. Transient expression of syndecan in mesenchymal cell aggregates of the embryonic kidney. Dev Biol 1992;152:221-32.

10. Landis SH, Murray T, Bolden S, Wingo PA. Cancer statistics. CA Cancer J Clin 1998;48:6-29.

11. Scully C, Field JK, Tanzawa H. Genetic aberrations in oral or head and neck squamous cell carcinoma (SCCHN): 1. Car- cinogen metabolism, DNA repair and cell cycle control. Oral Oncol 2000;36:256-63.

12. Inki P, Stenback F, Tavel L, Jalkanen M. Immunohistochemical localization of syndecan in mouse skin after skin tumors induced by UV irradiation. Loss of expression associated with malignant transformation. Am J Pathol 1991;139:133340.

13. Inki P, Joensuu H, Grenman R, Klemi P, Jalkanen M. Association between syndecan-1 expression and clinical outcome in squamous cell carcinoma of the head and neck. Br J Cancer 1994;70:319-23.

14. Pulkkinen JO, Pentitinen M, Jalkanen M, Klemi P, Grenman R. A new prognostic marker in laryngeal cancer. Acta Otolaryngol (Stockh) 1997;117:312-5.

15. Stanley M, Stanley MW, Sanderson RD, Zera R. Syndecan-1 expression is induced in the stroma of infiltrating breast carcinoma. Am J Clin Pathol 1999;112:377-83.

16. Wijdenes J, Vooijs WC, Clement C, Post J, Morard F, Vita N, et al. A plasmocyte selective monoclonal antibody (B-B4) recognizes syndecan-1. Br J Haematol 1996;94:318-23.

17. Anttonen A, Kajanti M, Heikkila P, Jalkanen M, Joensuu H. Syndecan-1 expression has prognostic significance in head and neck carcinoma. Br J Cancer 1999;79:558-64.

18. Iozzo R, Cohen I. Altered proteoglycan gene expression and the tumor stroma. Experientia 1993;49:447-55.

19. Kato M, Saunders S, Nguyen H, Bernfield M. Loss of cell surface syndecan-1 causes epithelia to transform into anchorage-independent mesenchyme-like cells. Mol Biol Cell 1995;6:559-76.

20. Inki P, Jalkanen M. The role of syndecan-1 in malignancies. Annu Rev Med 1996;28:63-7.

21. Mukunyadzi P, Sanderson RD, Fan C-Y, Smoller BR. The level of syndecan-1 expression is a distinguishing feature in behavior between keratoacanthoma and invasive cutaneous squamous cell carcinoma. Mod Pathol 2000;5:112-20.

22. Iacobuzio-Donahue CA, Argani P, Hempen PM, Jones J, Kern SE. The desmoplastic response to infiltrating breast carcinoma: gene expression at the site of primary invasion and implications for comparisons between tumor types. Cancer Res 2002;62:5351-7.

23. Elenius K, Salmivirta M, Inki P, Mali M, Jalkanen M. Binding of human syndecan to extracellular matrix proteins. J Biol Chem 1990;265:17834-43.

24. Kato M, Wang H, Kainulainen V, Fitzgerald ML, Ledbetter S, Ornitz DM, et al. Physiological degradation converts the soluble syndecan-1 ectodomain from an inhibitor to a potent activator of FGF-2. Nat Med 1998;4:691-7. 